SJ Quinney College of Law, University of Utah Utah Law Digital Commons

2019

Trump, Energy Policy, and Hard Look Review

Lincoln L. Davies

Tyler Hubbard

Christopher Sanders

Follow this and additional works at: https://dc.law.utah.edu/scholarship

Part of the Energy and Utilities Law Commons 


\section{THE OHIO STATE UNIVERSITY}

MORITZ COLLEGE OF LAW

Trump, Energy Policy, and Hard Look Review

Lincoln L. Davies

Tyler Hubbard

Christopher Sanders

Public Law and Legal Theory Working

Paper Series

No. 504

Rocky Mountain Mineral Law Foundation

Proceedings of the $64^{\text {th }}$ Annual Rocky Mountain Mineral Law Institute (2018)

September 16, 2019

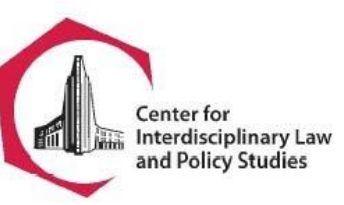

This working paper series is co-sponsored by the

Center for Interdisciplinary Law and Policy Studies at the Moritz College of Law

This paper can be downloaded without charge from the

Social Science Research Network:

http://ssrn.com/abstract=3454533 


\title{
TRUMP, ENERGY POLICY, AND HARD LOOK REVIEW
}

\author{
Lincoln L. Davies \\ Tyler Hubbard \\ Christopher Sanders \\ University of Utah S.J. Quinney College of Law \\ Salt Lake City, Utah
}

$\$ 21.01$ Introduction

$\$ 21.02$ Trump Energy Policy in Context

[1] Early Days

[2] Candidacy

[3] Presidency

$\$ 21.03$ Trump Energy Policy in Action

[1] Onshore Oil and Gas Development

[a] Waste Prevention Rule

[b] Fugitive Methane and Volatile Organic Compound Emission Limits

[2] Offshore Oil and Gas Development

[a] Outer Continental Shelf Drilling Areas

[b] National Marine Sanctuaries and Marine National Monuments

[3] Federal Coal Leasing

[4] The Clean Power Plan

[5] Vehicle Efficiency Standards

$\$ 21.04$ Hard Look Review

[1] The Law of Hard Look Review

[a] Motor Vehicle Manufacturers Ass'n v. State Farm Mutual Automobile Insurance Co.

[b] FCC v. Fox Television Stations, Inc.

[c] Encino Motorcars, LLC v. Navarro

[2] Hard Look Review in Practice

[a] Political Influence

[b] Prior Factual Records and Established Expectations

[3] Hard Look Review and the Trump Energy Policy

$\$ 21.05$ Conclusion 


\section{$\$ 21.01$ Introduction $^{* * *}$}

On January 6, 2014-nearly a year-and-a-half before declaring his candidacy-Donald J. Trump appeared by phone on the television program Fox \& Friends. When asked about climate change, Trump responded:

Well, it's a hoax. I think the scientists are having a lot of fun .... The problem we're doing is we're making our manufacturing ... non-competitive .... And if you look at what's going on in China, if you look at what's going on in India, they're not spending ten cents in their factories, and then we're supposed to compete. And you can't compete when you can't use fuel. ${ }^{1}$

And thus, in less than 30 seconds, Trump summarized what soon would become the crux of his energy policy as President of the United States.

For those concerned about climate change, the Trump administration's energy policy is alarming. It aims to unravel every corner of the Obama administration's climate legacy, consistent with an overall sweep of deregulation. Substantively, the Trump policy also departs starkly from the approach of the last decade, embracing traditional energy sources-fossil fuels and nuclear power-above all else.

${ }^{*}$ Cite as Lincoln L. Davies, Tyler Hubbard \& Christopher Sanders, “Trump, Energy Policy, and Hard Look Review," 64 Rocky Mt. Min. L. Inst. 21-1 (2018).

${ }^{* *}$ Lincoln L. Davies is the Hugh B. Brown Presidential Endowed Chair in Law and Associate Dean for Academic Affairs at the University of Utah S.J. Quinney College of Law. An internationally recognized expert in energy law and policy, Professor Davies is co-author of one of the nation's leading energy law casebooks, Energy Law and Policy (2d ed. 2018), as well as co-author with Joseph Tomain of an international treatise on U.S. energy law, Energy Law in the United States of America (2015). He has written extensively on energy, environmental, and administrative law, and in particular on renewables and alternative energy, rooftop solar, renewable portfolio standards and feed-in tariffs, nuclear energy, carbon capture and sequestration, and regulatory and technology innovation.

Tyler Hubbard is the Faust Research Fellow, S.J. Quinney College of Law, University of Utah.

Christopher Sanders is the Quinney Research Fellow, S.J. Quinney College of Law, University of Utah.

The authors are indebted to David Adelman, John Cossa, Keith Rizzardi, Peter Schaumberg, and Amy Wildermuth for helpful comments on an earlier draft, and to Emily Aplin, Melissa Bernstein, Suzanne Darais, Kerry Lohmeier, and Kiley Tilby for research assistance. A portion of this chapter draws on speeches Professor Davies gave for the Australian Institute of Energy (AIE) in July and August 2017. He is grateful to both AIE and the Rocky Mountain Mineral Law Foundation for the opportunity to address this important topic and, in particular, to John Blik, Steve Blume, Samantha Christie, Penny Crossley, David Deisley, Margo MacDonnell, Murray Meaton, James Prest, Charles Rendigs, Alex Ritchie, Albert Thompson, and Shawn Welch.

1 "Fox Regular Donald Trump Decries Climate Change 'Hoax': Attributes Climate Warnings to Scientists 'Having a Lot of Fun,'” Media Matters (from Fox News' Fox \& Friends (Jan. 6, 2014, 9:49 AM)), https://mediamatters.org/video/2014/01/06/fox-regular-donald-trump -decries-climate-change/197432. 
For those who favor President Trump's overarching political vision, however, there is much to applaud in this approach. The Trump energy policy aligns directly with his economic philosophy. As he noted on Fox $\&$ Friends, in his view, energy drives economic progress-and economic progress translates directly to international political power. Consequently, the Trump energy policy clutches at its heart the idea that returning to old energy patterns will resurrect a halcyon version of the United States: a middle-class-rich industrial export economy buoyed by U.S.-owned, U.S.-extracted, and U.S.-made energy.

To bring this vision to life, President Trump now is doing what the quasi-celebrity television commentator who appeared on Fox \& Friends never could. Swiftly and definitively, he has launched an all-out deregulatory offensive. At one level, this offensive feels unparalleled. It is, at least, unmatched since the Reagan era. At another level, it is hardly anything new. As the U.S. Supreme Court observed over 50 years ago, federal agencies "do not establish rules of conduct to last forever," but rather, "adapt their rules and practices to the Nation's needs in a volatile, changing economy." 2

The Trump administration's moves on energy thus beg the question: What limits, if any, does this policy approach face?

This chapter begins to answer that question. Employing the lens of arbitrary and capricious, or "hard look," review from administrative law, the chapter outlines principles that may constrain the Trump administration going forward-as well as areas where the administration has room to move.

Our contributions are threefold. First, we detail the pentagonal principles that define the Trump energy policy (yes, there is a policy). Second, we establish that this policy is highly political in nature, in that it both predates Trump's time in office and is connected to very specific projects and rules (even if that focus is short- rather than long-term). Third, we summarize the administration's efforts to date and then explain the ways in which hard look review is likely (or unlikely) to throw up barriers to those actions.

Four sections comprise the remainder of the chapter. Section 21.02 describes the Trump energy policy. Section 21.03 summarizes the actions the Trump administration has taken to implement this policy. Section 21.04 details the hard look doctrine and applies it, conceptually, to the Trump energy policy. Section 21.05 concludes.

${ }^{2}$ Am. Trucking Ass'ns v. Atchison, Topeka \& Santa Fe Ry. Co., 387 U.S. 397, 416 (1967). 


\section{$\$ 21.02$ Trump Energy Policy in Context}

For decades, a favorite pastime of U.S. politicians has been declaring that our nation has "no" energy policy. ${ }^{3}$ From Jimmy Carter to George W. Bush, the refrain is all too common. The echoes are so similar they are almost eerie. "Our country now," President Carter intoned in 1976, "has no comprehensive energy program or policy." ${ }^{4}$ In 2000, President George W. Bush readily agreed: "[O]ur country has a great and urgent need for a comprehensive energy policy ... Today, America has no energy policy ...."5

Given this long tradition, the Trump administration's approach marks a stark contrast. Out of the gate, Donald J. Trump-first the social media commenter, then the candidate, and now the President-has taken a different path from his predecessors. His claim has not been that the nation lacks an energy policy, either literally or by invoking the claim to demand change in a quasi-veiled way. ${ }^{6}$ Rather, President Trump asserts that the nation's policy under President Obama was flawed-and that it must be replaced by a new and better version, a policy that, as he says, puts "America first."

Perhaps it should not be surprising that President Trump has been so upfront about his energy agenda. Certainly his administration has not been coy about its aims in other contexts. ${ }^{8}$ Still, early on, the suggestion that the Trump administration had a coherent energy policy often was met as a somewhat startling revelation. Now, that reaction has subsided, as the administration's efforts over the last year-and-a-half have etched the policy's contours more plainly into view.

What is remarkable is that this policy did not crystallize during the campaign or even as the Trump presidency began. Instead, it arose from a loose conglomeration of ideas espoused by Donald Trump long before he was a serious contender for the White House. In short: There is a direct and unbroken line that can be traced from what the Trump administration is

\footnotetext{
${ }^{3}$ See Lincoln L. Davies, “Tracing U.S. Renewable Energy Policy," 43 Envtl. L. Rep. News \& Analysis 10320, 10321 (2013).

${ }^{4}$ Comm'n on Presidential Debates, "The First Carter-Ford Presidential Debate" (Sept. 23, 1976), http://www.debates.org/index.php?page=september-23-1976-debate-transcript.

${ }^{5}$ George W. Bush, Speech in Saginaw, Michigan: A Comprehensive National Energy Policy (Sept. 29, 2000) (transcript available at https://archive.li/o5aB1).

${ }^{6}$ See, e.g., Davies, supra note 3; Joseph P. Tomain, "The Dominant Model of United States Energy Policy," 61 U. Colo. L. Rev. 355 (1990).

${ }^{7}$ See Fact Sheet, White House, "President Donald J. Trump's Foreign Policy Puts America First" (Jan. 30, 2018).

${ }^{8}$ See Carol E. Lee, “Trump's Bluntness Unsettles World Leaders," Wall St. J. (Feb. 3, 2017). But cf. Bruce Brown \& Selina MacLaren, "Holding the Presidency Accountable: A Path Forward for Journalists and Lawyers," 12 Harv. L. \& Pol'y Rev. 89, 95 (2018) (noting the Trump administration's lack of transparency).
} 
doing on energy today, back to the promises Trump the candidate made, and then back even further to years of Trump's ubiquitous social media commentary.

This revelation-that the Trump energy policy has been extraordinarily consistent over time-is almost as important as context for understanding the policy as is detailing the content of the policy itself. It highlights how fully and thoroughly political the policy is-a fact that parties might rely on in trying to show that the policy shifts are untethered to the factual or scientific record.

\section{[1] Early Days}

Historians of a prior generation may either bemoan or marvel (or both) at reliance on 140- and 280-character missives as the primary source of a president's thoughts. But for someone who was not a public figure in any real sense prior to taking office, this, for now, is as good as it gets. Both the seeds and the roots of the Trump energy policy rest primarily in tweets.

The tweets are telling. Long before 2016, Mr. Trump lamented that the United States was not using its energy resources to play a larger-or different-role on the world economic stage. In September 2011, he declared: "If China had a tenth of the natural resources we do then they would already be energy independent. Instead we continue to buy oil from OPEC."9 The theme then continued. Just over a year later, Trump wrote: "Technology has shown we have tremendous energy resources right under our feet...."10 Then, the next month, this: "If we do not win energy as a country, we just do not win, period!"11

These ideas-that the United States needs to be not just energy independent but also ascendant, and that this kind of energy ascendancy equates to global economic domination-would later become the centerpiece of the Trump energy policy. He both foreshadowed and drove home the point in a 2014 missive: "If America unlocked its energy potential, we would once again be the most powerful country in the world." 12

Within this framework, three unconnected energy ideas consistently ran throughout Mr. Trump's pre-presidency social media political

\footnotetext{
${ }^{9}$ Donald J. Trump (@realDonaldTrump), Twitter (Sept. 16, 2011, 2:20 PM), https:// twitter.com/realDonaldTrump/status/114811039996063744.

${ }^{10}$ Donald J. Trump (@realDonaldTrump), Twitter (Sept. 19, 2012, 7:59 AM), https:// twitter.com/realDonaldTrump/status/248436233041215488.

${ }^{11}$ Donald J. Trump (@realDonaldTrump), Twitter (Oct. 17, 2012, 7:55 AM), https:// twitter.com/realDonaldTrump/status/258566974085423104.

${ }^{12}$ Donald J. Trump (@realDonaldTrump),Twitter (Apr. 21, 2014, 1:24 PM), https:// twitter.com/realDonaldTrump/status/458340513486475264.
} 
commentary. First, he repeatedly suggested that government regulation needlessly limits the energy industry. That was precisely the conclusion he used for his 2014 tweet asserting that energy could make the United States "the most powerful country in the world." That dream is possible, Trump said, but "Washington is holding us back."13 Less than two months later, he revisited the point: "Obama's war on coal is killing American jobs, making us more energy dependent on our enemies \& creating a great business disadvantage." 14

Second, Trump was unabashed about what energy sources he wanted to pick as winners. In his eyes, this was quite simple: Established energy sources-fossil fuels and nuclear power-are good. Emergent energy sources-renewables-are too expensive, unreliable, and bad. As Trump wrote in 2011, "OPEC is ripping us off on oil. We are ripping ourselves off by investing in unproven green energy." 15 The refrain was so common he even noted it himself. "Should have gone after the oil years ago," Trump tweeted in late 2015, "like I have been saying." 16 Thus, in Trump's mind, energy choices were easy and clear. "Fracking poses ZERO health risks" and "increases our national security by making us energy independent," he said. ${ }^{17}$ The Keystone XL Pipeline should be built because it "will create 20,000 jobs and lower gas prices. But Obama says No. Dumb."18 By contrast, renewables could only cause problems in Trump's view. The Obama administration, Trump said, "pissed away" billions of dollars on "green energy' failures." 19 "It is a shame Keystone wasn't powered by solar panels and wind because then @BarackObama would have wasted billions on it," he lamented in 2012. ${ }^{20}$ And Trump repeatedly voiced his distaste for wind energy, perhaps colored by his feud with a wind project near his golf course

\footnotetext{
${ }^{13} I d$.

${ }^{14}$ Donald J. Trump (@realDonaldTrump),Twitter (June 3, 2014, 11:32 AM), https:// twitter.com/realdonaldtrump/status/473895061747695616.

${ }^{15}$ Donald J. Trump (@realDonaldTrump), Twitter (Sept. 23, 2011, 10:56 AM), https:// twitter.com/realdonaldtrump/status/117296270682497024.

16Donald J. Trump (@realDonaldTrump), Twitter (Dec. 6, 2015, 5:28 PM), https:// twitter.com/realdonaldtrump/status/673675346030542848.

${ }^{17}$ Donald J. Trump (@realDonaldTrump), Twitter (May 1, 2013, 12:17 PM), https:// twitter.com/realdonaldtrump/status/329676026382790656.

${ }^{18}$ Donald J. Trump (@realDonaldTrump), Twitter (Dec. 27, 2011, 12:53 PM), https:// twitter.com/realdonaldtrump/status/151767567604781058.

${ }^{19}$ Donald J. Trump (@realDonaldTrump), Twitter (Apr. 25, 2013, 12:49 PM), https:// twitter.com/realdonaldtrump/status/327509770716213248.

${ }^{20}$ Donald J. Trump (@realDonaldTrump), Twitter (Jan. 24, 2012, 12:27 PM), https:// twitter.com/realdonaldtrump/status/161908088851529728.
} 
in Scotland. ${ }^{21}$ "Wind turbines are ripping your country apart and killing tourism. Electric bills in Scotland are skyrocketing-stop the madness," Trump tweeted in March 2014.22

Third, Trump consistently expressed skepticism about climate change and its role in energy policy. Sometimes these views confused basic definitional differences between weather and climate, such as his tweet from February 2014: "Massive record setting snowstorm and freezing temperatures in U.S. Smart that GLOBAL WARMING hoaxsters changed name to CLIMATE CHANGE! $\$ \$ \$ \$ . "{ }^{23}$ Often, the tweets falsely implied (or flatly stated) that climate change lacks scientific support, such as his tweet from January 2014: "Give me clean, beautiful and healthy air - not the same old climate change (global warming) bullshit!" 24 And always, they saw the idea of regulating climate change as antithetical to his economic views. "The concept of global warming," Trump famously tweeted in November 2012, "was created by and for the Chinese in order to make U.S. manufacturing non-competitive." 25

\section{[2] Candidacy}

As the Trump presidential candidacy took shape, so too did its energy policy. And as that policy emerged, it was hard not to notice that it sprang directly from the scattered political claims on energy that Mr. Trump had been reciting in the years prior.

By far, Mr. Trump's most important speech on energy as a presidential candidate came the same day he reached the threshold of delegates to clinch the Republican nomination. It was May 26, 2016, in Bismarck, North Dakota. Using the Williston Basin Petroleum Conference as a platform to announce his plan, Trump outlined an energy policy that aligned almost point for point with his earlier social media commentary.

Trump began by reemphasizing the idea that energy wealth is linked to economic wealth-and that economic wealth determines global political

\footnotetext{
${ }^{21}$ See, e.g., Philip Bump, “Trump's Decade-Long Fight with Scotland Is Why He Thinks Putin Wanted Clinton to Win," Wash. Post (July 12, 2017).

${ }^{22}$ Donald J. Trump (@realDonaldTrump), Twitter (Mar. 19, 2014, 5:00 PM), https:// twitter.com/realdonaldtrump/status/446436045178302464.

${ }^{23}$ Donald J. Trump (@realDonaldTrump),Twitter (Feb. 5, 2014, 2:57 AM), https:// twitter.com/realdonaldtrump/status/431018674695442432.

${ }^{24}$ Donald J. Trump (@realDonaldTrump), Twitter (Jan. 28, 2014, 10:44 PM), https:// twitter.com/realdonaldtrump/status/428418323660165120.

${ }^{25}$ Donald J. Trump (@realDonaldTrump),Twitter (Nov. 6, 2012, 11:15 AM), https:// twitter.com/realdonaldtrump/status/265895292191248385.
} 
power. "A Trump administration will develop an America First energy plan," Trump proclaimed. "America first, folks, America first!"26

He then hinted at a theme he would later emphasize as president. Prior administrations repeatedly had called for the United States to become "energy independent." 27 Trump, however, saw that goal as too low. Instead, he suggested the United States should seek energy "dominance." He explained: " $[\mathrm{H}]$ ere is how we're going to do it. And here is how this plan will make America wealthy again. American energy dominance will be declared a strategic economic and foreign policy goal of the United States. It's about time." ${ }^{28}$ This, Trump said, was possible because the United States enjoys tremendous energy wealth. "We're loaded," Trump repeatedly exclaimed in Bismarck. "[W]e didn't even know it. We're loaded! We had no idea how rich we were. We're richer than all of 'em . . .."29

With these broad objectives in place, Mr. Trump then laid out what he called his 100-day energy action plan. Consistent with his previously expressed views, this plan focused on promoting fossil fuels, rolling back Obama-era regulations, and stepping away from efforts to engage in climate mitigation. "[W]e're going to rescind all the job-destroying Obama executive actions, including the Climate Action Plan," Trump declared. "[O]kay? Remember that. We're going to save the coal industry! We're gonna save that coal industry! Believe me, we're gonna save it! I love those people - these are great people!" 30 In particular, Trump indicated that he wanted to pave the way for the Keystone XL Pipeline, going so far as to say he would specifically "ask Trans-Canada to renew its permit application." ${ }^{31}$ $\mathrm{He}$ also said that he would "lift moratoriums on energy production in federal areas," "revoke policies that impose unwarranted restrictions on new drilling technologies," and "cancel" the Paris Climate Agreement. ${ }^{32}$

${ }^{26}$ Donald Trump, Speech at Williston Basin Petroleum Conf. in Bismarck, N.D., May 26, 2016: An America First Energy Plan, YouTube, https://www.youtube.com/watch?v= kxq9lBnv0cs (transcript available at http://www.astrologicaltools.com/energy).

${ }^{27}$ See Michael Burger, "Recovering from the Recovery Narrative: On Glocalism, Green Jobs and Cyborg Civilization," 46 Akron L. Rev. 909, 919 (2013).

${ }^{28}$ Trump, supra note 26.

${ }^{29} I d$.

${ }^{30} \mathrm{Id}$.

${ }^{31} I d$.

${ }^{32} I d$.; see also Donald J. Trump for President, Inc., "An America First Energy Plan," https://web.archive.org/web/20161110003503/https://www.donaldjtrump.com/policies/ energy/. 


\section{[3] Presidency}

By the time Mr. Trump was sworn into office, then, the energy policy he was espousing was clear. It was built on five pillars. First, above all else, was the idea of promoting U.S. energy production and exports, consistent with his overall "America first" approach to economic and foreign affairs. Second was an underlying assumption that U.S. energy sources are not meaningfully limited, such that both energy "independence" and "dominance" are possible. Next was the idea that an onslaught of regulatory rollbacks was needed to achieve these goals. The fourth pillar of his policy was the promotion of fossil fuels and a concomitant distaste for renewables. And last was a strong version of explicit climate skepticism, namely, that any regulation seeking to rein in climate change is inappropriate by definition.

While this policy was plain as Mr. Trump took office, the President further etched it into place in June 2017, when he gave his second key speech on energy to date, at an event entitled Unleashing American Energy during the administration's "Energy Week." In the speech, President Trump drew even clearer connections between his energy and economic policies. Repeatedly referencing fossil fuels, he asserted: "The truth is that we have near-limitless supplies of energy in our country.... We have nearly 100 years' worth of natural gas and more than 250 years' worth of clean, beautiful coal." 33 This, Trump said, puts the United States "really in the driving seat" because energy wealth is the key to international power. ${ }^{34}$ Thus, U.S. energy wealth, he said, will unlock "a true energy revolution" that in turn will promote national "sovereignty" and economic progress. ${ }^{35}$ "With these incredible resources, my administration will seek not only American energy independence that we've been looking for so long, but American energy dominance. And we're going to be an exporter-exporter. We will be dominant. We will export American energy all over the world, all around the globe." 36

Thus the fully political nature of the Trump administration's energy policy was laid bare. Not only was the policy moored in the overarching themes on which President Trump had run for office, it was expressly pitched as a direct response to the prior administration. Not only did the policy try to recast the world of energy as something different from what had actually developed over prior decades, it sought to speak specifically to constituencies that had been harmed by the increasing globalization and

\footnotetext{
${ }^{33}$ Remarks, White House, "Remarks by President Trump at the Unleashing American Energy Event” (June 29, 2017).

${ }^{34} I d$.

${ }^{35} \mathrm{Id}$.

${ }^{36} I d$.
} 
technologization of the economy. And not only did the policy lay out broad objectives that were political in nature, it named specific programs, projects, and regulations it would target in pursuit of those goals-irrespective of the government's prior factual determinations that such policies were needed.

\section{$\$ 21.03$ Trump Energy Policy in Action}

Presaged by the announcement of its 100-day energy action plan in Bismarck, the Trump administration wasted little time putting its policy into place. The President, virtually on being sworn into office, issued three executive orders to begin the play.

The second was the most important. Entitled "Promoting Energy Independence and Economic Growth" and issued March 28, 2017, Executive Order No. 13,783 mandated a bevy of actions centered on undoing the Obama administration's work. ${ }^{37}$ It rescinded President Obama's Climate Action $\mathrm{Plan}^{38}$ and connected orders, including guidance on how to account for climate change in federal environmental reviews. ${ }^{39}$ It ordered federal agencies to review and potentially roll back a wide array of regulations, including the Clean Power Plan, the Obama administration's moratorium on federal coal leasing, and rules on methane and other climate change emissions in the oil and gas sector. And it compelled agency heads to evaluate "all existing regulations, orders, guidance documents," and other agency actions that "potentially burden the development or use of domestically produced energy resources, with particular attention to oil, natural gas, coal, and nuclear energy resources." 40 Thus the order declared it in the national interest to develop "our Nation's vast energy resources" and to reduce "regulatory burdens that unnecessarily encumber energy production ...." ${ }^{41}$ In short, the order formalized the President's Bismarck energy policy-a policy that equates traditional energy development with economic success.

The other two executive orders pursued complementary tactics. Executive Order No. 13,776, issued January 24, 2017, and entitled "Expediting Environmental Reviews and Approvals for High Priority Infrastructure Projects," created a process by which state governors and federal agency

\footnotetext{
${ }^{37}$ Exec. Order No. 13,783, 82 Fed. Reg. 16,093 (Mar. 28, 2017).

${ }^{38}$ Exec. Office of the President, “The President's Climate Action Plan” (June 2013).

${ }^{39}$ The plan sought to "slow the effects of climate change" by cutting carbon emissions. $I d$. at 5 . The plan consisted of "a wide variety of executive actions." Id. In conjunction with the plan, the Council on Environmental Quality also issued guidance for considering greenhouse gas (GHG) emissions in NEPA reviews. See 81 Fed. Reg. 51,866 (Aug. 5, 2016).

${ }^{40}$ Exec. Order No. 13,783, \$2(a).

${ }^{41} I d . \$ 1(\mathrm{a})$.
} 
heads could request "high priority" expedited review of energy and other infrastructure projects. ${ }^{42}$ Executive Order No. 13,795, issued April 28, 2017, and entitled "Implementing an America-First Offshore Energy Strategy," declared it national policy to "encourage energy exploration and production, including on the Outer Continental Shelf [(OCS)], in order to maintain the Nation's position as a global energy leader." ${ }^{43}$ This order reversed certain limits on offshore oil and gas leasing and commanded the review of multiple rules and designations applicable to the industry.

The stage was set, then, for the Trump administration to put its energy policy into action. The action was immediate. During his first week in office, the President, first, formally invited TransCanada Keystone Pipeline, LP to "promptly re-submit its application to the Department of State" to construct the Keystone XL Pipeline ${ }^{44}$ and, second, directed the U.S. Army Corps of Engineers (Corps) to "take all actions necessary and appropriate" to "review and approve in an expedited manner" the Dakota Access Pipeline (DAPL) project. ${ }^{45}$ Two months later to the day, the Secretary of State granted a presidential permit for the Keystone XL Pipeline. ${ }^{46}$ Then, in even less time, the Corps green-lighted the DAPL project. ${ }^{47} \mathrm{~A}$ few months later, the President announced that the United States would withdraw from the Paris Climate Agreement because it "punishes the United States ... while imposing no meaningful obligations on the world's leading polluters." 48 "I was elected to represent the citizens of Pittsburgh," the President declared, "not Paris." 49

The administration's orientation was thus clear. It put the public on notice that its actions would be swift and numerous-and that it would

\footnotetext{
${ }^{42}$ Exec. Order No. 13,766, 82 Fed. Reg. 8657 (Jan. 24, 2017).

${ }^{43}$ Exec. Order No. 13,795, § 2, 82 Fed. Reg. 20,815 (Apr. 28, 2017).

${ }^{44}$ Presidential Memorandum on Construction of the Keystone XL Pipeline $₫ 2,82$ Fed. Reg. 8663 (Jan. 24, 2017).

${ }^{45}$ Presidential Memorandum on Construction of the Dakota Access Pipeline $\$ 2(a), 82$ Fed. Reg. 11,129 (Jan. 24, 2017).
}

${ }^{46}$ Press Release, U.S. Dep’t of State, "Issuance of Presidential Permit to TransCanada for Keystone XL Pipeline” (Mar. 24, 2017).

${ }^{47}$ See Memorandum from Paul D. Cramer, Deputy Assistant Sec'y of the Army, to Hon. Raul Grijalva, U.S. House of Representatives (Feb. 7, 2017) (notice to Congress and others of the Corps' intent to grant an easement for DAPL for 30 years); News Release, Corps, "Corps Grants Easement to Dakota Access, LLC" (Feb. 8, 2017); Notice of Termination of Intent to Prepare an EIS in Connection with Dakota Access, LLC's Request for an Easement to Cross Lake Oahe, North Dakota, 82 Fed. Reg. 11,021 (Feb. 17, 2017).

${ }^{48}$ Remarks, White House, "Statement by President Trump on the Paris Climate Accord" (June 1, 2017).

${ }^{49} \mathrm{Id}$. 
vigorously seek to promote domestic fossil fuels and traditional industry while erasing all regulations focused on climate change, just as the President had promised on the campaign trail. It also highlighted the trajectory these actions would follow: They would provoke extensive litigation, ${ }^{50}$ and their symbolic value would often exceed their actual impact.

Indeed, the Trump administration's energy actions to date are so frequent, copious, and divergent, they defy easy summary. Here, then, we focus on the five most prominent categories of action so far: onshore and offshore oil and gas development, federal coal leasing, the Clean Power Plan, and vehicle fuel efficiency standards.

\section{[1] Onshore Oil and Gas Development}

The Trump administration's actions to promote onshore oil and gas development trace directly to the President's "energy independence" executive order. That order directed the U.S. Environmental Protection Agency (EPA) and the Secretary of the Interior to review-and presumably unravel-a series of Obama-era rules designed to reduce greenhouse gas (GHG) emissions from this industry. ${ }^{51}$ The agencies wasted little time. Already, they have sought to delay, revoke, and replace both of the Obama administration's key rules in this realm: the Waste Prevention Rule, plus a separate set of EPA regulations on fugitive methane and other emissions.

\section{[a] Waste Prevention Rule}

Arguably the most critical onshore oil and gas rule targeted by the Trump administration is the Waste Prevention Rule.52 Promulgated in November 2016, this rule aimed to limit methane and other fugitive gas emissions from all onshore oil and gas projects on federal and tribal lands. When the Obama administration adopted the rule, data showed that these projects vented, flared, or otherwise lost enough natural gas in the prior six years to "supply about 6.2 million households for a year." 53

The rule thus implemented a goal of reducing methane leakage in federal and tribal oil and gas projects by $2026 .{ }^{54}$ Specifically, the rule required

\footnotetext{
${ }^{50}$ See, e.g., Third Amended Complaint for Declaratory and Injunctive Relief, N. Plains Res. Council v. Shannon, No. 4:17-cv-00031 (D. Mont. Aug. 4, 2017); Complaint for Declaratory and Injunctive Relief, Indigenous Envtl. Network v. U.S. Dep't of State, No. 4:17-cv00029 (D. Mont. Mar. 27, 2017); Standing Rock Sioux Tribe v. Corps, 255 F. Supp. 3d 101 (D.D.C. 2017) (order on cross-motions for partial summary judgment).

${ }^{51}$ Exec. Order No. 13,783, 82 Fed. Reg. 16,093 (Mar. 28, 2017).

${ }^{52}$ Waste Prevention, Production Subject to Royalties, and Resource Conservation, 81 Fed. Reg. 83,008 (Nov. 18, 2016) (to be codified at 43 C.F.R. pts. 3100, 3160, 3170).

${ }^{53}$ Fact Sheet, BLM, "Methane Waste Prevention Rule," at 1 (Nov. 15, 2016).

5481 Fed. Reg. at 83,011.
} 
oil and gas operators to capture specific percentages of produced natural gas, measure how much they flare, develop waste minimization plans, and upgrade or replace certain equipment. ${ }^{55}$ The rule also redefined what counted as "unavoidably lost" and "avoidably lost" oil and gas (i.e., "waste"), and imposed limits on venting and flaring. ${ }^{56}$

Out of the gate, the Trump administration sought to reverse the Waste Prevention Rule. The first avenue it pursued was the Congressional Review Act. ${ }^{57}$ That effort initially gained some traction, passing the House 221 to $191 .{ }^{8}$ Ultimately, however, the effort foundered in the Senate, failing on a 49 to 51 vote. ${ }^{59}$

Unmoved, the Trump administration turned to executive action instead. On June 15, 2017, the Bureau of Land Management (BLM) issued a notice stating that it would postpone compliance dates for several portions of the rule pending resolution of litigation challenging the rule in the U.S. District Court for the District of Wyoming. ${ }^{60}$ The BLM claimed it had authority to postpone implementation under section 705 of the Administrative Procedure Act (APA). That provision allows an agency, when "justice so requires," to "postpone the effective date of action taken by it, pending judicial review." ${ }^{1}$ "Considering the substantial cost that complying with these requirements poses to operators," the BLM wrote, "and the uncertain future these requirements face in light of the pending litigation," postponement was appropriate. ${ }^{62}$

Almost immediately, the BLM's effort devolved into a legal ping-pong match. The U.S. District Court for the Northern District of California found the BLM's delay unlawful. ${ }^{63}$ Then, the very next day, the BLM proposed

\footnotetext{
${ }^{55} \mathrm{Id}$.

${ }^{56} I d$. at $83,011,83,047-48$.

575 U.S.C. $\$ \$ 801-808$.

${ }^{58}$ H.R.J. Res. 36, 115th Cong. (2017).

${ }^{59}$ See Juliet Eilperin \& Chelsea Harvey, "Senate Unexpectedly Rejects Bid to Repeal a Key Obama-Era Environmental Regulation," Wash. Post (May 10, 2017).

${ }^{60}$ The postponement applied only to the portions of the rule that were not already in effect.

615 U.S.C $\$ 705$; see also Waste Prevention, Production Subject to Royalties, and Resource Conservation; Postponement of Certain Compliance Dates, 82 Fed. Reg. 27,430 (June 15, 2017).

6282 Fed. Reg. at $27,431$.

${ }^{63}$ California v. BLM, 277 F. Supp. 3d 1106 (N.D. Cal. 2017) (order granting plaintiffs' motions for summary judgment).
} 
a new postponement until January 17, 2019. ${ }^{64}$ This time, the BLM abandoned its APA $₫ 705$ argument and instead cited a slate of statutes it said gave the agency "inherent" authority "to modify or otherwise revise the existing regulation in response to substantive concerns regarding cost and feasibility ...." "65

This, though, was not the end of the volley. On February 22, 2018, the Northern District of California found this new delay also arbitrary and capricious and enjoined the postponement. ${ }^{66}$ "[The BLM] must provide at least some basis," the court wrote, "indeed, a 'detailed justification'-to explain why it is changing course after its three years of study and deliberation resulting in the Waste Prevention Rule."67

Still undeterred, the Trump administration deployed a third strategy for lifting the rule. On the same day the court struck down the BLM's second attempt at postponement, the agency proposed a new rule to replace the Obama administration's version. ${ }^{68}$ Specifically, this proposal would rescind key provisions of the Waste Prevention Rule and make other changes. First, it would terminate the waste capture percentage requirements on the grounds that they are "overly complex and ultimately ineffective at reducing flaring." 69 Second, it would withdraw the waste minimization, leak detection, equipment repair, and reporting requirements on the grounds that compliance costs "outweigh the value of their conservation effects." 70 Third, the proposal would return to the pre-Obama standards for determining when gas is "avoidably" or "unavoidably" lost—and change the venting prohibition to a venting "limitation" that gives operators significant leeway to vent or flare gas much as they had in the past. ${ }^{71}$

The BLM set a deadline of April 23, 2018, for public comments on its proposal. Meanwhile, the Trump administration notched a victory. On

${ }^{64}$ Waste Prevention, Production Subject to Royalties, and Resource Conservation; Delay and Suspension of Certain Requirements, 82 Fed. Reg. 46,458 (proposed Oct. 5, 2017) (to be codified at 43 C.F.R. pts. 3160,3170 ).

${ }^{65}$ Waste Prevention, Production Subject to Royalties, and Resource Conservation; Delay and Suspension of Certain Requirements, 82 Fed. Reg. 58,050, 58,059 (Dec. 8, 2017) (to be codified at 43 C.F.R. pts. 3160, 3170).

${ }^{66}$ California v. BLM, 286 F. Supp. 3d 1054 (N.D. Cal. 2018) (order denying motion to transfer venue and granting preliminary injunction).

${ }^{67} \mathrm{Id}$. at 1068 .

${ }^{68}$ Waste Prevention, Production Subject to Royalties, and Resource Conservation; Rescission or Revision of Certain Requirements, 83 Fed. Reg. 7924 (proposed Feb. 22, 2018) (to be codified at 43 C.F.R. pts. 3160,3170 ).

${ }^{69} \mathrm{Id}$. at 7930 .

${ }^{70} \mathrm{Id}$. at 7932 .

${ }^{71}$ Id. at $7933-34$. 
April 4, 2018, in response to a request from the BLM, the District of Wyoming enjoined multiple provisions of the Waste Prevention Rule. ${ }^{72}$ Two days later, California and New Mexico appealed that decision to the U.S. Court of Appeals for the Tenth Circuit. ${ }^{73}$

\section{[b] Fugitive Methane and Volatile Organic Compound Emission Limits}

To complement the Waste Prevention Rule, the Obama EPA also issued limits on fugitive GHG and volatile organic compound (VOC) emissions for new oil and gas drilling, including hydraulically fractured sites. ${ }^{74}$ This rule imposed a wide array of requirements to limit methane and VOC emissions, including 95\% methane emission reductions at well sites, zero natural gas bleed rates at processing plants, and zero natural gas emissions at processing pumps. ${ }^{75}$

Quickly-though less successfully than with the Waste Prevention Rule-the Trump administration sought to lift these requirements as well. First, the EPA initiated a review and gave advanced notice of a forthcoming rulemaking, suggesting that the Obama-era rule was too costly. ${ }^{76}$ Then, two months later, the EPA stayed the Obama rules twice, first for 90 days, ${ }^{77}$ and 10 days later, for two years. ${ }^{78}$ To justify these actions, the EPA cited "uncertainties" regarding the rule's application. ${ }^{79}$

This effort, however, kept for only about a month. On July 3, 2017, the U.S. Court of Appeals for the D.C. Circuit vacated the EPA's stay, rejecting

${ }^{72}$ Wyoming v. DOI, No. 2:16-cv-00285 (D. Wyo. Apr. 4, 2018) (order staying implementation of rule provisions and staying action pending finalization of revision rule).

${ }^{73}$ State Respondents' Notice of Appeal, Wyoming v. DOI, No. 2:16-cv-00285 (D. Wyo. Apr. 6, 2018).

${ }^{74}$ Oil and Natural Gas Sector: Emission Standards for New, Reconstructed, and Modified Sources, 81 Fed. Reg. 35,824 (June 3, 2016) (to be codified at 40 C.F.R. pt. 60).

${ }^{75} \mathrm{Id}$. at 35,826 .

${ }^{76}$ See Review of the 2016 Oil and Gas New Source Performance Standards for New, Reconstructed, and Modified Sources, 82 Fed. Reg. 16,331 (Apr. 4, 2017); see also Letter from E. Scott Pruitt, EPA Adm'r, to Howard J. Feldman et al., "Convening a Proceeding for Reconsideration of Final Rule, 'Oil and Natural Gas Sector: Emission Standards for New, Reconstructed and Modified Sources', published June 3, 2016, 81 Fed. Reg. 35824” (Apr. $18,2017)$.

${ }^{77}$ Oil and Natural Gas Sector: Emission Standards for New, Reconstructed, and Modified Sources; Grant of Reconsideration and Partial Stay, 82 Fed. Reg. 25,730 (June 5, 2017).

${ }^{78}$ Oil and Natural Gas Sector: Emission Standards for New, Reconstructed, and Modified Sources: Stay of Certain Requirements, 82 Fed. Reg. 27,645 (proposed June 16, 2017) (to be codified at 40 C.F.R. pt. 60).

${ }^{79} 82 \mathrm{Fed}$. Reg. at 25,733 . 
the agency's claim that it had " "inherent authority' to 'issue a brief stay.' " 80 The EPA, wrote the court, "cites nothing for the proposition that it has such authority, and for good reason .... [The Clean Air Act] confers no such authority." ${ }^{11}$ Accordingly, the court ordered the Obama-era rule to be implemented beginning July $31,2017 .{ }^{82}$

\section{[2] Offshore Oil and Gas Development}

The Trump administration's actions to date for offshore resources are more focused on encouraging production than reducing costs. The efforts fall into two key categories: expanding the portion of the OCS open for drilling and reviewing prior national marine sanctuary and marine national monument designations. ${ }^{83}$

\section{[a] Outer Continental Shelf Drilling Areas}

For decades, the portion of the OCS open to offshore drilling has been quite limited. ${ }^{84}$ Of the four broad regions of the OCS-the Alaskan, Atlantic, Gulf of Mexico, and Pacific-only the Gulf of Mexico is widely open to new drilling. Most portions of the others have not seen new leases issued since the $1980 \mathrm{~s}^{85}$ This trend began when President George H.W. Bush issued a drilling moratorium in 1990, later extended by President Clinton,

${ }^{80}$ Clean Air Council v. Pruitt, 862 F.3d 1, 9 (D.C. Cir. 2017).

${ }^{81} \mathrm{Id}$.

${ }^{82}$ See Mandate Issued to EPA, Clean Air Council v. Pruitt, No. 17-1145 (D.C. Cir. July 31, 2017). Subsequently, the EPA removed two Obama-era fugitive emissions requirementsthe "requirement that leaking components be repaired during unplanned or emergency shutdowns; and the monitoring survey requirements for well sites located on the Alaskan North Slope." Fact Sheet, EPA, "EPA Amends Portion of Fugitive Emissions Requirements in the 2016 New Source Performance Standards for the Oil and Natural Gas Industry" (Feb. 23, 2018); see also Oil and Natural Gas Sector: Emission Standards for New, Reconstructed, and Modified Sources; Amendments, 83 Fed. Reg. 10,628 (Mar. 12, 2018) (to be codified at 40 C.F.R. pt. 60).

${ }^{83}$ Consistent with the offshore executive order's direction, agencies are also reviewing offshore well control rules adopted after the Deepwater Horizon disaster. See Oil \& Gas and Sulfur Operations in the OCS-Blowout Preventer Systems and Well Control, 81 Fed. Reg. 25,888 (Apr. 29, 2016) (to be codified at 30 C.F.R. pt. 250); Air Quality Control, Reporting, and Compliance, 81 Fed. Reg. 19,718 (proposed Apr. 5, 2016) (to be codified at 30 C.F.R.pt. 550); Oil \& Gas and Sulfur Operations on the OCS-Requirements for Exploratory Drilling on the Arctic OCS, 81 Fed. Reg. 46,478 (July 15, 2016) (to be codified at 30 C.F.R. pts. 250, $254,550)$.

${ }^{84}$ See Hiroko Tabuchi \& Tim Wallace, “Trump Would Open Nearly All U.S. Waters to Drilling. But Will They Drill?” N.Y. Times (Jan. 23, 2018); see also Adam Vann, Cong. Research Serv., "Offshore Oil and Gas Development: Legal Framework" (CRS Report RL33404 Apr. 13, 2018).

${ }^{85}$ See Am. Petroleum Inst., "Unlocking America’s Offshore Energy," https://www.api.org/ oil-and-natural-gas/energy-primers/offshore. 
and then augmented by President Obama. ${ }^{86}$ Thus, while the OCS consists of approximately 1.8 billion acres, only about 178 million acres are available for oil and gas leasing, and just over 41 million acres are currently under lease-with only 8 million acres, or less than $0.5 \%$ of the OCS, actually producing. ${ }^{87}$

President Trump's offshore energy executive order sought to change this. It specifically aimed to reverse the arguably permanent withdrawals from leasing that President Obama ordered in 2015 and 2016 for the U.S. Arctic (the Beaufort and Chukchi Seas) and certain deep canyons in the Atlantic. ${ }^{88}$ It also directed the Secretary of the Interior to reconsider issuing oil and gas leases "to the maximum extent permitted by law" in multiple OCS planning areas. ${ }^{89}$

This direction had swift effect. On January 8, 2018-eight months after the President issued the offshore executive order-the Bureau of Ocean Energy Management (BOEM) officially proposed opening all but one region of the OCS for leasing through 2024. ${ }^{90}$ This proposal "would make more than 98 percent of the OCS resources available to consider for oil and gas leasing during the 2019-2024 period."91 The agency requested public comments by March 9, 2018, and noted that it would conduct a programmatic environmental impact review on its planned leasing schedule. ${ }^{92}$

Already, these actions have engendered litigation. On May 3, 2017, a coalition of environmental public interest groups filed suit seeking declaratory and injunctive relief, challenging the executive order's attempt to undo

${ }^{86}$ See Democratic Policy \& Commc'ns Comm., U.S. Senate, "Clean Energy Jobs and Oil Company Accountability Act: Background on Offshore Drilling and Moratoriums," https://www.dpc.senate.gov/files_energybill/background_offshore.pdf. President Obama withdrew 3.8 million acres of the Atlantic region and 115 million acres of the Arctic region from development. See Press Release, U.S. Dep't of the Interior (DOI), "Secretary Jewell Applauds President's Withdrawal of Atlantic and Arctic Ocean Areas from Future Oil and Gas Leasing" (Dec. 20, 2016).

${ }^{87}$ Inst. for Energy Research, "Outer Continental Shelf (OCS) Statistics" (June 23, 2008), http://instituteforenergyresearch.org/analysis/outer-continental-shelf-ocs-statistics/.

${ }^{88}$ Exec. Order No. 13,795, 82 Fed. Reg. 20,815 (Apr. 28, 2017); see Presidential Memorandum on Withdrawal of Certain Areas of the United States Outer Continental Shelf Offshore Alaska from Leasing Disposition (Jan. 27, 2015); Presidential Memorandum on Withdrawal of Certain Areas off the Atlantic Coast on the Outer Continental Shelf from Mineral Leasing (Dec. 20, 2016).

${ }^{89}$ Exec. Order No. 13,795, § 3(a).

${ }^{90}$ See Notice of Availability of the 2019-2024 Draft Proposed OCS Oil \& Gas Leasing Program and Notice of Intent to Prepare a Programmatic EIS, 83 Fed. Reg. 829 (Jan. 8, 2018).

${ }^{91} \mathrm{Id}$. at 830 .

${ }^{92} \mathrm{Id}$. at 829. 
President Obama's permanent withdrawal from leasing of the Beaufort and Chukchi Seas and the deep canyon Atlantic areas. ${ }^{93}$ The parties argue that while section 12(a) of the Outer Continental Shelf Lands Act ${ }^{94}$ gives authority for presidential withdrawal of unleased OCS lands, it does not authorize "Presidents to undo such withdrawals."95 As of this writing, the lawsuit remains pending. On March 19, 2018, the court denied the government's various motions to dismiss. ${ }^{96}$

\section{[b] National Marine Sanctuaries and Marine National Monuments}

In response to the offshore drilling executive order, the National Oceanic and Atmospheric Administration (NOAA) announced that it would review 11 National Marine Sanctuaries and Marine National Monuments within the OCS that had been designated or expanded within the last 10 years. ${ }^{97}$ In total, these areas encompass around 425 million acres. ${ }^{98}$ NOAA also invited comments on a variety of factors it would consider, including costs of managing the areas and overall opportunity costs if the areas are opened to development. ${ }^{99}$ In response, NOAA received nearly 100,000 comments, with approximately $99 \%$ of those urging the agency to keep the designations in place. ${ }^{100}$

In October 2017, NOAA submitted a final report to the White House. The report, however, remains in interagency review and has not been made available to the public. ${ }^{101}$ Several environmental groups have pledged to sue should the sanctuaries and monuments be eliminated or reduced.102

\footnotetext{
${ }^{93}$ See Complaint for Declaratory and Injunctive Relief, League of Conservation Voters v. Trump, No. 3:17-cv-00101 (D. Alaska May 3, 2017), 2017 WL 1736693.

9443 U.S.C. $\$ 1341(\mathrm{a})$.

${ }^{95}$ Complaint, supra note 93, at 1 .

${ }^{96}$ League of Conservation Voters v. Trump, 303 F. Supp. 3d 985 (Mar. 19, 2018).

${ }^{97}$ Review of National Marine Sanctuaries and Marine National Monuments Designated or Expanded Since April 28, 2007, 82 Fed. Reg. 28,827, 28,828 (June 26, 2017).

${ }^{98}$ See id.

${ }^{99} \mathrm{Id}$.

${ }^{100}$ See Paul Rogers, "Trump Gets Report that Could Open National Marine Sanctuaries to Oil Drilling," Mercury News (Oct. 27, 2017).

${ }^{101}$ See Valerie Volcovici, "U.S. Marine Sanctuary Oil Drilling Report Sent to Trump, Not Public," Reuters (Oct. 25, 2017).

${ }^{102}$ See Rogers, supra note 100.
} 


\section{[3] Federal Coal Leasing}

The Trump administration's actions on federal coal leasing parallel those for offshore oil and gas development. ${ }^{103}$ They are a direct response to the Obama administration's withdrawal of federal lands for energy development. They aim to increase fossil fuel production.

These objectives flow directly from the "energy independence" executive order. That order expressly directed the Secretary of the Interior to "take all steps necessary and appropriate to amend or withdraw" the Obamaera moratorium on new coal leasing on federal lands. ${ }^{104}$ The day after President Trump issued the executive order, Secretary of the Interior Ryan Zinke signed his own order seeking to implement these goals. ${ }^{105}$

Specifically, Secretary Zinke's order both repealed the moratorium and eliminated the procedural framework undergirding it. In issuing the moratorium in 2016, then-Secretary Sally Jewell detailed concerns about coal market conditions and climate change as the grounds for halting new leases. ${ }^{106}$ The idea was that while the moratorium was in place, the BLM would conduct a programmatic environmental impact statement (PEIS) of the federal coal program, including coal market conditions. ${ }^{107}$ Prior to this order, the federal government had not conducted a comprehensive review of its coal leasing program in nearly four decades. ${ }^{108}$

Secretary Zinke's order, however, ended the moratorium and terminated the PEIS effort. Noting that both the moratorium and the PEIS were

${ }^{103}$ While we focus here on federal and tribal coal development, the Trump administration has been busy seeking to promote coal in other ways. These efforts include (1) proposing changes to coal ash regulation; (2) repealing a rule that sought to close royalty payment loopholes; and (3) pursuing a variety of strategies to ensure that coal is used for electricity production, including by invoking little-used emergency and other statutory provisions. See News Release, EPA, "EPA Proposes First of Two Rules to Amend Coal Ash Disposal Regulations, Saving Up To \$100M Per Year in Compliance Costs" (Mar. 1, 2018); Repeal of Consolidated Federal Oil \& Gas and Federal \& Indian Coal Valuation Reform, 82 Fed. Reg. 36,934 (Aug. 7, 2017) (to be codified at 30 C.F.R. pts. 1202, 1206); Stephen Lacey \& Julia Pyper, "DOE's Grid Reliability Study Is a Rorschach Test for the Future of Electricity," Greentech Media (Aug. 23, 2017); Gavin Bade, "'FERC Did Its Job:' Former Regulators, Lawyers Laud DOE NOPR Rejection," Utility Dive (Jan. 9, 2018); White House, "Statement from the Press Secretary on Fuel-Secure Power Facilities" (June 1, 2018); Gavin Bade, "FERC Regulators: No Security Emergency to Justify DOE Coal, Nuke Bailout," Utility Dive (June 12, 2018).

${ }^{104}$ Exec. Order No. 13,783, $\$ 6,82$ Fed. Reg. 16,093 (Mar. 28, 2017). The moratorium had limited exceptions, including for metallurgical coal, lease modifications, and emergency leasing. See Secretarial Order No. 3338, \$ 6 (Jan. 15, 2016) (SO 3338).

${ }^{105}$ Secretarial Order No. 3348 (Mar. 29, 2017) (SO 3348).

${ }^{106}$ SO 3338, supra note 104 , at $\$ 2$.

${ }^{107} I d . \S 5$.

${ }^{108}$ See id. $\$ 2$. 
discretionary, Secretary Zinke's two-page order found the moratorium "not ... [in] the public interest" and the PEIS unnecessary "to consider potential improvements to the program." 109 The PEIS, in particular, the order explained, would "cost many millions of dollars and would be completed no sooner than 2019." 110 Accordingly, Secretary Zinke directed the BLM to begin "process[ing] coal lease applications and modifications expeditiously" and ordered "[a]ll activities associated with" the PEIS to cease. ${ }^{111}$

Now, two lawsuits seek to block Secretary Zinke's actions. First, a coalition of environmental groups along with the Northern Cheyenne Tribe have filed suit challenging Secretary Zinke's order as inconsistent with the National Environmental Policy Act of 1969 (NEPA). ${ }^{112}$ Second, four states-California, New Mexico, New York, and Washington-have challenged the moratorium dissolution as both violative of NEPA ${ }^{113}$ and inconsistent with the Mineral Leasing Act of $1920^{114}$ and the Federal Land Policy and Management Act of 1976. ${ }^{115}$ Both cases are in the U.S. District Court for the District of Montana, which has consolidated the suits. ${ }^{116}$

\section{[4] The Clean Power Plan}

Also aiming to promote coal, the Trump administration has sought to unravel what many hailed as the United States' "strongest ever climate action"117 - the Obama administration's Clean Power Plan (CPP). ${ }^{118}$ In October 2015, after hundreds of meetings, years of deliberation, and millions of public comments, ${ }^{119}$ the Obama administration finalized this rule

${ }^{109}$ SO 3348 , supra note 105 , at $\$ 4$.

${ }^{110} I d . \S 3$.

${ }^{111} I d$. $\$ 5$. In addition, Congress rescinded the Stream Protection Rule, which sought to limit environmental damage from mountaintop removal coal mining. See Stream Protection Rule, 81 Fed. Reg. 93,066 (Dec. 20, 2016) (to be codified in scattered sections of 30 C.F.R.), disapproved by H.R.J. Res. 38, Pub. L. No. 115-5, 131 Stat. 10 (2017).

${ }^{112}$ Complaint for Declaratory and Injunctive Relief, Citizens for Clean Energy v. DOI, No. 4:17-cv-00030 (D. Mont. Mar. 29, 2017), 2017 WL 1173696; see 42 U.S.C. $\$ \$ 4321-4347$.

${ }^{113}$ Complaint for Declaratory and Injunctive Relief at 3, California v. DOI, No. 4:17-cv00042 (D. Mont. May 9, 2017), 2017 WL 1862941.

11430 U.S.C. $\$ \$ 181-263$.

11543 U.S.C. $\$ \$ 1701-1782$.

${ }^{116}$ Citizens for Clean Energy v. DOI, No. 4:17-cv-00030 (D. Mont. June 2, 2017) (order granting motion to consolidate cases).

${ }^{117}$ Adam Vaughan, “Obama's Clean Power Plan Hailed as US's Strongest Ever Climate Action," Guardian (Aug. 3, 2015).

${ }^{118}$ See Carbon Pollution Emission Guidelines for Existing Stationary Sources: Electric Utility Generating Units, 80 Fed. Reg. 64,662 (Oct. 23, 2015) (to be codified at 40 C.F.R. pt. 60).

${ }^{119} I d$. at 64,704 . 
seeking to reduce electricity sector GHG emissions by nearly one-third of 2005 levels by 2030. ${ }^{120}$ Although the CPP's details were complex, the basic approach was straightforward: The EPA would set carbon dioxide $\left(\mathrm{CO}_{2}\right)$ emissions reduction targets, and states would implement plans to achieve those goals. ${ }^{121}$

Almost immediately, the CPP became embroiled in litigation. Twentynine states and over a dozen electric utilities sued, claiming the EPA had exceeded its authority under the Clean Air Act (CAA). ${ }^{122}$ Specifically, the parties asserted that CAA $\$ 111(\mathrm{~d}),{ }^{123}$ which the EPA relied on in issuing the CPP, did not grant authority to regulate GHG emissions from electric power plants-and that the CPP was otherwise unlawful. ${ }^{124}$ In response, on February 9, 2016, the U.S. Supreme Court, by a 5-4 vote, took the unusual step ${ }^{125}$ of issuing a stay enjoining the EPA from enforcing the CPP pending litigation. ${ }^{126}$ Consequently, the CPP never took full effect, and 19 states suspended their efforts to develop individual compliance plans. ${ }^{127}$

The Trump administration took equally quick action to dismantle the CPP. The President appointed Oklahoma Attorney General Scott Pruitt, a noted critic of both the CPP and the EPA, to head that agency. ${ }^{128} \mathrm{~A}$ week after the President issued his "energy independence" executive order, the EPA announced that it was, consistent with that order, conducting a review of the CPP and providing advance notice of "forthcoming" rulemaking

${ }^{120} \mathrm{Id}$. at 64,665 .

${ }^{121}$ See EPA, "Legal Memorandum Accompanying Clean Power Plan for Certain Issues," at $1,6,23$, https://www.epa.gov/sites/production/files/2015-11/documents/cpp-legalmemo.pdf.

${ }^{122}$ See Robinson Meyer, “The Supreme Court's Devastating Decision on Climate," The Atlantic (Feb. 10, 2016).

${ }^{123} 42$ U.S.C. $\$ 7411$.

${ }^{124}$ Petition for Review, West Virginia v. EPA, No. 15-1363 (D.C. Cir. Oct. 23, 2015).

${ }^{125}$ This was the first time the Court had ever blocked an EPA rule using a stay. See Lawrence Hurley \& Valerie Volcovici, "U.S. Supreme Court Blocks Obama’s Clean Power Plan," Scientific Am. (Feb. 9, 2016).

${ }^{126}$ West Virginia v. EPA, 136 S. Ct. 1000 (2016).

${ }^{127}$ See, e.g., E\&E News, “E\&E’s Power Plan Hub," https://www.eenews.net/interactive/ clean_power_plan\#planning_status. Twenty-eight states continued their efforts.

${ }^{128}$ See Brady Dennis, "Scott Pruitt, Longtime Adversary of EPA, Confirmed to Lead the Agency," Wash. Post (Feb. 17, 2017); see also, e.g., Letter from E. Scott Pruitt, EPA Adm'r, to Hon. Matt Bevin, Governor of Ky. (Mar. 30, 2017) (informing the Governor that EPA's policy in light of the CPP stay was that "States have no obligation to spend resources to comply with a Rule that has been stayed"). 
proceedings reflecting that review. ${ }^{129}$ Six months later, the EPA proposed to repeal the CPP altogether. ${ }^{130}$

In proposing this repeal, the EPA, in a stark about-face, concluded that the CPP exceeded its authority under section $111(\mathrm{~d})$. This was because, the agency said, the rule compelled utilities to "change their energy portfolios" away from GHG-heavy fuels like coal to other alternatives like natural gas or renewables, rather than following usual agency practice of setting "emission guidelines" for power plants. ${ }^{131}$ This was problematic, the EPA reasoned, because it "necessitate[s] changes to a state's energy policy,"132 thus extending federal authority too far.

Since announcing this repeal, the EPA has been holding a variety of public hearings. ${ }^{133}$ It set January 16, 2018, as the deadline for public comments, which it later extended to April 26, 2018. ${ }^{134}$ While repeal of the CPP remains a proposal for now, it is a virtual certainty that litigation will ensue once the EPA does move forward. ${ }^{135}$

\section{[5] Vehicle Efficiency Standards}

Consistent with the administration's overall plan to roll back all Obamaera climate regulations, President Trump also has sought to undo his predecessor's efforts to increase vehicle efficiency. Following passage of the Energy Independence and Security Act of 2007,136 and the Supreme Court's decision in Massachusetts v. EPA, ${ }^{137}$ the Obama EPA and National Highway Traffic Safety Administration (NHTSA) jointly finalized new

${ }^{129}$ See Review of the CPP, 82 Fed. Reg. 16,329 (Apr. 4, 2017). The EPA also withdrew two CPP-related proposals. See Withdrawal of Proposed Rules: Federal Plan Requirements for GHG Emissions from Electric Utility Generating Units Constructed On or Before January 8, 2014; Model Trading Rules; Amendments to Framework Regulations; and Clean Energy Incentive Program Design Details, 82 Fed. Reg. 16,144 (Apr. 3, 2017).

${ }^{130}$ See Repeal of Carbon Pollution Emission Guidelines for Existing Stationary Sources: Electric Utility Generating Units, 82 Fed. Reg. 48,035 (proposed Oct. 16, 2017) (to be codified at 40 C.F.R. pt. 60).

${ }^{131}$ Id. at 48,037 .

${ }^{132} \mathrm{Id}$.

${ }^{133}$ See Repeal of Carbon Pollution Emission Guidelines for Existing Stationary Sources: Electric Utility Generating Units, 82 Fed. Reg. 51,787 (Nov. 8, 2017) (announcement of public hearing).

${ }^{134}$ See Repeal of Carbon Pollution Emission Guidelines for Existing Stationary Sources: Electric Utility Generating Units, 83 Fed. Reg. 4620 (Feb. 1, 2018) (announcement of public listening sessions and extension of public comment period).

${ }^{135}$ See Debra Kahn, “West Coast States Protest Repeal, Threaten Lawsuits," Climate Wire (Mar. 1, 2018).

${ }^{136}$ Pub. L. No. 110-140, 121 Stat. 1492.

137549 U.S. 497 (2007). 
Corporate Average Fuel Economy (CAFE) standards requiring car manufacturers to meet fleet-wide efficiency averages of 54.5 miles per gallon by $2025 .{ }^{138}$ Addressing climate change was at the heart of this effort. The agencies estimated that their rule would reduce GHG emissions by an equivalent of 2 billion metric tons of $\mathrm{CO}_{2}$ and save nearly 4 billion barrels of oil consumption. ${ }^{139}$

Less than two months after President Trump took office, however, the EPA and NHTSA announced their intention to reconsider this Obama-era rule. ${ }^{140}$ Although the EPA had decided only months earlier to keep the standards in place, the March 22, 2017, notice of reconsideration stressed that agencies have "inherent authority to reconsider past decisions" and announced a review of the rules to be completed by April 1, 2018. ${ }^{141}$ The EPA then opened this review to comment ${ }^{142}$ and received nearly 300,000 responses. ${ }^{143}$

A few months later, in April 2018, then-EPA Administrator Pruitt announced that he was reversing the agency's prior determination not to alter the Obama-era CAFE standards. ${ }^{144}$ Those standards, he said, were "based on outdated information" and potentially "too stringent." 145 Specifically, he said he had determined that the standards created feasibility "challenges for auto manufacturers," raised "potential" safety concerns, and imposed "significant additional costs on consumers, especially low-income consumers." 146 Accordingly, the EPA declared the existing CAFE standards "[o]n the whole ... not appropriate" and announced that it would,

${ }^{138} 2017$ and Later Model Year Light-Duty Vehicle GHG Emissions and Corporate Average Fuel Economy Standards, 77 Fed. Reg. 62,624, 69,627 (Oct. 15, 2012) (to be codified at 40 C.F.R. pts. $85,86,600$ and 49 C.F.R. pts. 523, 531, 533, 536, 537).

${ }^{139}$ Id.

${ }^{140}$ See Notice of Intention to Reconsider the Final Determination of the Mid-Term Evaluation of GHG Emissions Standards for Model Year 2022-2025 Light Duty Vehicles, 82 Fed. Reg. 14,671 (Mar. 22, 2017).

${ }^{141} I d$. at $14,671,14,672$.

${ }^{142}$ See Request for Comment on Reconsideration of the Final Determination of the Mid-Term Evaluation of GHG Emissions Standards for Model Year 2022-2025 Light-Duty Vehicles; Request for Comment on Model Year 2021 GHG Emissions Standards, 82 Fed. Reg. 39,551 (Aug. 21, 2017).

${ }^{143}$ Meanwhile, NHTSA announced that it would delay implementing increases to civil penalties for failure to comply with CAFE regulations. See Civil Penalties, 81 Fed. Reg. 95,489 (Dec. 28, 2016) (to be codified at 49 C.F.R. pt. 578); Civil Penalties, 82 Fed. Reg. 32,139 (July 12, 2017) (delay of effective date).

${ }^{144}$ See Mid-Term Evaluation of GHG Emissions Standards for Model Year 2022-2025 Light-Duty Vehicles, 83 Fed. Reg. 16,077 (Apr. 13, 2018).

${ }^{145} I d$. at 16,077 .

${ }^{146} \mathrm{Id}$. at 16,078 . 
with NHTSA, "further explore" new changes via notice-and-comment rulemaking. ${ }^{147}$

Within weeks, 17 states plus the District of Columbia challenged the EPA's determination in the D.C. Circuit. ${ }^{148}$ The parties claim that EPA's decision is arbitrary and capricious, inconsistent with the agency's own regulations, and in violation of the CAA. ${ }^{149}$

Then, on August 1, 2018, the EPA continued its efforts to roll back Obama-era CAFE standards. It issued a notice of proposed rulemaking seeking to amend the requirements for passenger cars and light trucks, by freezing the standards at 2020 levels through 2026. ${ }^{150}$

\section{$\$ 21.04$ Hard Look Review}

Part of what complicates the nation's energy future under President Trump is the filtering lens of administrative law. Indeed, the very process of de- or re-regulation following a change in presidents inevitably invokes a host of administrative law principles. ${ }^{151}$ These run the gamut from procedural hurdles to deference questions under Chevron, ${ }^{152}$ Skidmore, ${ }^{153}$ and their ilk. ${ }^{154}$

When agencies switch policy positions, however, arguably the most central doctrine is arbitrary and capricious-or hard look-review. ${ }^{155}$ This principle, though flexible, constrains agencies by seeking to ensure that they both justify their decisions and do not shift course without merit. Thus, while the judiciary has expressly condoned the practice of agency policy change-including for political motivations-the executive branch does not enjoy carte blanche to evolve its policies willy-nilly.

${ }^{147} I d$. at $16,087$.

${ }^{148}$ See Press Release, Office of Governor of Cal., "California and States Representing Over 40 Percent of U.S. Car Market Sue to Defend National Clean Car Rules" (May 1, 2018); see also Petition for Review, California v. EPA, No. 18-1114 (D.C. Cir. May 1, 2018).

${ }^{149}$ See Press Release, supra note 148.

${ }^{150}$ The Safer Affordable Fuel-Efficient (SAFE) Vehicles Rule for Model Years 2021-2026 Passenger Cars and Light Trucks, 83 Fed. Reg. 42,986 (Aug. 24, 2018).

${ }^{151}$ See generally Bethany A. Davis Noll \& Denise A. Grab, "Deregulation: Process and Procedures that Govern Agency Decisionmaking in an Era of Rollbacks," 38 Energy L.J. 269 (2017).

${ }^{152}$ Chevron, U.S.A., Inc. v. Natural Res. Def. Council, Inc., 467 U.S. 837 (1984).

${ }^{153}$ Skidmore v. Swift \& Co., 323 U.S. 134 (1944).

${ }^{154}$ Bowles v. Seminole Rock \& Sand Co., 325 U.S. 410 (1945).

${ }^{155}$ See 5 U.S.C. $\$ 706(2)(A)$; Emily Hammond Meazell, "Deference and Dialogue in Administrative Law," 111 Colum. L. Rev. 1722, 1733 (2011). 


\section{[1] The Law of Hard Look Review}

Hard look review often is taken as a misnomer. This is because the inquiry's overarching objective is supposed to focus on whether the agency took a hard look at the problem, not for courts to do so themselves. The reality, of course, is that anytime a court overturns an agency's decision as arbitrary and capricious, it will feel like the court subjected the agency's choice to some amount of searching scrutiny.

Courts recite the arbitrary and capricious standard in a variety of formulations. The classic statement is that an agency fails hard look review if it has (1) "relied on factors which Congress has not intended it to consider," (2) "entirely failed to consider an important aspect of the problem," (3) "offered an explanation for its decision that runs counter to the evidence before the agency," or (4) "is so implausible that it could not be ascribed to a difference in view or the product of agency expertise." 156

Thus, there are minimum thresholds an agency must meet for its decision to pass the arbitrary and capricious threshold. The agency "must examine the relevant data and articulate a satisfactory explanation for its action."157 It must draw a "rational connection between the facts found and the choice made." 158 And it "must give adequate reasons for its decisions"159_including explaining itself such that the path of its logic "may reasonably be discerned." 160

Under this "narrow" scope of review, "a court is not to substitute its judgment for that of the agency." ${ }^{161}$ However, courts do not conduct the review "merely to rubber stamp agency actions." 162 Instead, the review is "flexible" 163 and acts "as a check upon administrators whose zeal might otherwise have carried them to excesses" 164 by carefully balancing judicial review and "agency autonomy." 165

${ }^{156}$ Meazell, supra note 155, at 1733 (quoting Motor Vehicle Mfrs. Ass'n v. State Farm Mut. Auto. Ins. Co., 463 U.S. 29, 43 (1983)).

${ }^{157}$ State Farm, 463 U.S. at 43.

${ }^{158} I d$. (quoting Burlington Truck Lines, Inc. v. United States, 371 U.S. 156, 168 (1962)).

${ }^{159}$ Encino Motorcars, LLC v. Navarro, 136 S. Ct. 2117, 2125 (2016).

${ }^{160}$ Id. (quoting Bowman Transp., Inc. v. Ark.-Best Freight Sys., Inc., 419 U.S. 281, 286 (1974)).

161 State Farm, 463 U.S. at 43.

${ }^{162}$ Natural Res. Def. Council, Inc. v. Daley, 209 F.3d 747, 755 (D.C. Cir. 2000).

${ }^{163}$ Natural Res. Def. Council, Inc. v. SEC, 606 F.2d 1031, 1050 (D.C. Cir. 1979).

${ }^{164}$ United States v. Morton Salt Co., 338 U.S. 632, 644 (1950).

${ }^{165}$ Albert W. Vanderlaan, Note, "Sending a Message to the Other Branches: Why the Second and Third Circuits Properly Used the APA to Rule on Fleeting Expletives and How the New FCC Can Undo the Damage," 34 Vt. L. Rev. 447, 463 (2009). 
A trilogy of U.S. Supreme Court cases spanning three-and-a-half decades illustrates the doctrine's contours.

\section{[a] Motor Vehicle Manufacturers Ass'n v. State Farm Mutual Automobile Insurance Co.}

The U.S. Supreme Court's seminal decision on hard look review is Motor Vehicle Manufacturers Ass'n v. State Farm Mutual Automobile Insurance Co. ${ }^{166}$ This case arose from a regulatory move directly parallel to the Trump administration's current efforts. President Reagan's campaign focused heavily on a broad promise of deregulation, ${ }^{167}$ including for automakers. ${ }^{168}$ In State Farm, the Supreme Court evaluated the permissibility of one such deregulatory effort: NHTSA's rescission of airbag and automatic seatbelt requirements for new vehicles.

Expressly acknowledging that agency rules need not be permanently engraved in stone, the Court nonetheless overturned NHTSA's rescission as arbitrary and capricious. This was for both substantive and procedural reasons.

First, NHTSA gave no consideration to amending the prior, Carter-era rule to require that only airbags be used, rather than airbags or automatic seatbelts. ${ }^{169}$ The agency's complete failure to "even consider the possibility" of an airbags-only option, the Court unanimously held, rendered this deregulatory choice unlawful. ${ }^{170}$

Second, the Court, by a 5-4 margin, also found the agency "too quick to dismiss the safety benefits of automatic seatbelts." 171 Specifically, the Court ruled that while it might have been justifiable to eliminate this rule, the agency's record did not support its ultimate conclusion. This was because theNHTSA neither addressed the difference between detachable automatic and manual seatbelts nor explained why it did not simply require nondetachable automatic seatbelts. ${ }^{172}$

\footnotetext{
166463 U.S. 29 (1983).

${ }^{167}$ See James F. Blumstein, "Regulatory Review by the Executive Office of the President: An Overview and Policy Analysis of Current Issues," 51 Duke L.J. 851, 859 (2001).

${ }^{168}$ See Kathryn A. Watts, "Proposing a Place for Politics in Arbitrary and Capricious Review," 119 Yale L.J. 2, 59 (2009).

${ }^{169}$ State Farm, 463 U.S. at 46.

${ }^{170} \mathrm{Id}$. at 48 .

${ }^{171} I d$. at 51.

${ }^{172} I d$. at $52-53$.
} 


\section{[b] FCC v. Fox Television Stations, Inc.}

Arguably the U.S. Supreme Court's most important arbitrary and capricious decision since State Farm came in 2009 in FCC v. Fox Television Stations, Inc. ${ }^{173}$ Fox involved mirror image facts to State Farm.

In Fox, the Federal Communications Commission (FCC), under President George W. Bush, sought to impose more onerous indecency restrictions on television broadcasters. Specifically, the FCC's new policy, "for the first time," found that nonliteral uses of "the F- and S-Words" during live television broadcasts "could be actionably indecent, even when the word is used only once." 174 Despite the agency's sharp break with past practice, the Court upheld the FCC's new enforcement policy.

The Court began by declining the broadcasters' invitation to impose a more rigorous standard of review simply because the agency had changed policy positions. Rather, the Court found "no basis" in the APA or its own precedent "for a requirement that all agency change be subjected to more searching review." 175 Indeed, as the Court noted, "State Farm neither held nor implied that every agency action representing a policy change must be justified by reasons more substantial than those required to adopt a policy in the first instance." 176

That threshold question settled, the Court found the agency's new policy justified by the factual record. The FCC, the Court said, "acknowledged that its recent actions [had] broken new ground," and then backed up that choice with reasons that "were entirely rational." 177 These included that "[e]ven isolated utterances" can be vulgar and that "a safe harbor for single words would 'likely lead to more widespread use of the offensive language." 178

\section{[c] Encino Motorcars, LLC v. Navarro}

Most recently, the U.S. Supreme Court completed its hard look trilogy in Encino Motorcars, LLC v. Navarro. ${ }^{179}$ Unlike State Farm and Fox, this case involved not the repeal or tightening of a regulation, but rather the sudden volte-face of one.

${ }^{173} 556$ U.S. 502 (2009); see Jodi L. Short, "The Political Turn in American Administrative Law: Power, Rationality, and Reasons," 61 Duke L.J. 1811, 1813 (2012).

${ }^{174}$ Fox, 556 U.S. at 508.

${ }^{175} \mathrm{Id}$. at 514 .

${ }^{176} I d$.

${ }^{177} \mathrm{Id}$. at 517 .

${ }^{178} I d$. at 518 (quoting In re Complaints Against Various Broadcast Licenses Regarding the Airing of the "Golden Globe Awards" Program, 19 FCC Rcd. 4975, 4979 (2004)).

${ }^{179} 136$ S. Ct. 2117 (2016). 
Encino Motorcars arose out of the Obama Department of Labor's (DOL) decision to reverse a prior regulation that exempted "service advisors" at car dealerships from overtime compensation. ${ }^{180}$ In deciding whether this policy flip-flop was arbitrary and capricious, the Court reiterated its stance from Fox: "When an agency changes its existing position, it 'need not always provide a more detailed justification than what would suffice for a new policy created on a blank slate." 181 But, the Court emphasized, the agency must provide a "reasoned explanation" for its about-face. ${ }^{182}$ An unexplained inconsistency in agency policy is grounds for judicial invalidation. ${ }^{183}$

By a 7-2 vote, the Court found the DOL's policy reversal unlawful. First - and unlike the broadcasters in Fox - the retail automobile and truck dealership industry had relied on the prior DOL rule for decades, negotiating and structuring their compensation plans against the backdrop of that rule. ${ }^{184}$ Second-and unlike the FCC in Fox-the DOL "said almost nothing" in the way of "good reasons for the new policy." 185 Instead of offering a reasoned explanation for its change, the DOL simply asserted that its regulation was "reasonable." ${ }^{186}$ Because "[i]t is not the role of the courts to speculate on reasons that might have supported an agency's decision," the Court found the new regulation insufficient under hard look review. ${ }^{187}$

\section{[2] Hard Look Review in Practice}

The State Farm trilogy thus established a trinity of principles that guide arbitrary and capricious review. First, agencies may alter their policies over time. Second, agencies must acknowledge when they are changing policy positions. ${ }^{188}$ And third, agencies must justify their new policies-but the "reasons for the new policy" need not be "better than the reasons for the old one." 189

These principles are key to understanding the ground rules that govern a common situation for agencies: They want to alter, amend, or rescind

\footnotetext{
${ }^{180} \mathrm{Id}$. at 2123 .

${ }^{181}$ Id. at 2125 (quoting Fox, 556 U.S. at 515).

${ }^{182} I d$.

${ }^{183} I d$. at 2126.

${ }^{184} I d$.

${ }^{185}$ Id. at 2127 (quoting Fox, 556 U.S. at 515).

${ }^{186} I d$.

${ }^{187} I d$.

${ }^{188}$ See also Nehemiah Corp. of Am. v. Jackson, 546 F. Supp. 2d 830, 842 (E.D. Cal. 2008).

${ }^{189}$ Fox, 556 U.S. at 515.
} 
existing policy positions, whether because facts have changed, their approach is not working, or politics have shifted, including through a change in presidents. ${ }^{190}$ State Farm, Fox, and Encino Motorcars, however, only provide an initial glimpse into how stringently courts actually review changes in agencies' policy positions.

Here, then, we explore two doctrines that often come into play when agencies reverse or alter policy: first, that political influence generally does not expressly factor into courts' hard look calculus, and second, that prior factual records and reliance interests may, in effect, constrain agency leeway.

\section{[a] Political Influence}

The U.S. Supreme Court has never fully answered the question of "how courts should approach agency decisions relying on political pressure rather than expert analysis." ${ }^{191}$ The debate traces to at least State Farm itself. There, Justice Rehnquist-joined by three other justices-contended that administrative policy shifts deriving from a presidential change are presumptively justified, because they arguably reflect the democratic choice of the people. ${ }^{192}$

Nonetheless, courts typically have not countenanced political motivations in their express arbitrary and capricious analyses. ${ }^{193}$ Instead, the question of politics tends to lurk beneath the surface, seemingly influencing courts' starting points in ineluctable ways, but remaining notably absent from their explicit focus on the agency record itself.

Thus, more than one commentator has argued for recasting the hard look standard in light of the role that politics inevitably plays in agency decision making. ${ }^{194}$ As then-Professor Kagan suggested, an "alternative" vision of hard look review "centered on the political leadership and accountability provided by the President" might offer a more honest appraisal for how courts actually see these questions. ${ }^{195}$

Indeed, one possible reading of State Farm is that what the Court really wanted was for the agency to tell "the full story" and thus "be forced 'to

\footnotetext{
${ }^{190}$ See Encino Motorcars, 136 S. Ct. at 2125.

${ }^{191}$ Eric Berger, "Individual Rights, Judicial Deference, and Administrative Law Norms in Constitutional Decision Making," 91 B.U. L. Rev. 2029, 2080-81 (2011).

${ }^{192}$ Motor Vehicle Mfrs. Ass'n v. State Farm Mut. Auto. Ins. Co., 463 U.S. 29, 59 (1983).

${ }^{193}$ See Watts, supra note 168 , at 6.

${ }^{194}$ See, e.g., Berger, supra note 191, at 2080-81.

${ }^{195}$ Elena Kagan, “Presidential Administration,” 114 Harv. L. Rev. 2245, 2380 (2001).
} 
reveal the political basis for its decisions.' "196 Under such a reading, an agency's action is more likely to be arbitrary and capricious if it fails to disclose how politics influenced its decision. Encino Motorcars arguably underscores this point. As one commentator has noted, that case sent the message that agencies "can't just get away with ... political flip-flops," especially without justifying them. ${ }^{197}$

By contrast, other decisions seem to cut wide paths for agencies to change directions even for overtly political reasons. Fox may lead the field. As one commentator has suggested, Fox presumptively "makes it easier for agencies to change their policies" based on politics, particularly since the dissent there lost the argument that the lack of a higher standard of review allows regulation to "bend too readily before the political winds." 198

Given this tension in U.S. Supreme Court precedent, it should not be surprising that courts tend not to focus on political influence in hard look review, at least at face value. Still, at least one court has struck down as arbitrary and capricious an agency decision where it detected improper political influence. In Tummino $v$. Torti, ${ }^{199}$ the U.S. District Court for the Eastern District of New York found unlawful the Food and Drug Administration's (FDA) refusal to allow women under age 17 to use the Plan B emergency contraceptive without a prescription. ${ }^{200}$ The court began by observing that it is generally unlawful for agencies to act in "subjective bad faith." 201 The court then found that the FDA had displayed a "lack of good faith," in part, because it acted pursuant to "pressure emanating from the White House" and anti-abortion constituents rather than making its own decision based on the facts. ${ }^{202}$ Specifically, the court noted that the FDA Commissioner had discussed the pending decision with a subordinate who was in contact with the White House, and then "made [the] decision before FDA staff had completed their scientific reviews of [the] data." 203

${ }^{196}$ Kathryn A. Watts, "Controlling Presidential Control," 114 Mich. L. Rev. 683, 743-44 (2016) (quoting Lisa Schultz Bressman, "Procedures as Politics in Administrative Law," 107 Colum. L. Rev. 1749, 1783 (2007)).

${ }^{197}$ Dialogue, "The Future of Administrative Law: DOJ/ENRD Symposium on the Future of Environmental Law," 47 Envtl. L. Rep. News \& Analysis 10185, 10193 (2017) (statement of Professor Richard J. Pierce, Jr.).

${ }^{198}$ Watts, supra note 168, at 10; see FCC v. Fox Television Stations, Inc., 556 U.S. 502, 547 (2009) (Breyer, J., dissenting).

${ }^{199} 603$ F. Supp. $2 d 519$ (E.D.N.Y. 2009), amended sub nom. Tummino v. Hamburg, No. 1:05-cv-00366, 2013 WL 865851 (E.D.N.Y. Mar. 6, 2013).

${ }^{200} \mathrm{Id}$. at 546.

${ }^{201}$ Id. at 542.

${ }^{202} \mathrm{Id}$. at 544 .

${ }^{203} I d$. at 530. 
Tummino has been characterized as an unusual case, and it may be. Nonetheless, the case offers a toehold for other courts to strike down agency actions where political influence appears to be driving the result. ${ }^{204}$ How far that reasoning can extend is the question. At least some observers think not far. As two commentators recently argued: "So long as agencies can articulate some reasoned defense based on statutory terms, even if some political factor drove the decision, courts can manage to ignore politics. The charade disintegrates only when the agency has no facially plausible alternative story it can tell." ${ }^{205}$

In short, while political influence may well color how a court engages in hard look review, relying on that idea as the sole rationale for attacking agency policy flip-flops is not a path well-trodden in administrative law jurisprudence.

\section{[b] Prior Factual Records and Established Expectations}

While State Farm and its progeny appear to embrace-rather than resolve-the tension over how much politics may drive agency decision making, courts have developed a corollary doctrine that may nevertheless constrain agencies seeking to alter their approach based on politics. In such cases, the U.S. Supreme Court has ruled, agencies must provide a more detailed justification if either of two circumstances exist: (1) the "new policy rests upon factual findings that contradict those which underlay its prior policy," or (2) the prior policy has created "serious reliance interests." 206

The factual finding point manifests in the contrast between State Farm and Fox. In State Farm, NHTSA failed hard look review because it "did not address its prior factual findings." ${ }^{207}$ By contrast, in Fox, the FCC's policy flip-flop passed muster because the agency "did not base its prior policy on factual findings."208

${ }^{204}$ Contra Cook Inlet Beluga Whale v. Daley, 156 F. Supp. 2d 16, 22 (D.D.C. 2001) (although political considerations may have affected the decision not to list the Cook Inlet Beluga Whale under the Endangered Species Act (ESA), the evidence "did not establish that, but for 'politics', the whale would have been listed under the ESA or that political considerations became part of the decision making process").

${ }^{205}$ Daniel A. Farber \& Anne Joseph O’Connell, “The Lost World of Administrative Law," 92 Tex. L. Rev. 1137, 1168 (2014) (footnote omitted).

${ }^{206}$ FCC v. Fox Television Stations, Inc., 556 U.S. 502, 515 (2009).

${ }^{207} \mathrm{Id}$. at 538 (Kennedy, J., concurring in part and concurring in the judgment).

${ }^{208} I d$. 
Organized Village of Kake v. USDA ${ }^{209}$ provides another example. That case arose out of the U.S. Department of Agriculture's (USDA) 2001 "Roadless Rule," which "limit[ed] road construction and timber harvesting in national forests." 210 The USDA originally found that exempting the Tongass National Forest "would risk the loss of important [ecological] values." ${ }^{211}$ But in 2003, after President George W. Bush's election, the agency-relying on the same 2001 record-reversed course and found it "unnecessary" to apply the rule to the Tongass National Forest. ${ }^{212}$ The U.S. Court of Appeals for the Ninth Circuit found this reversal arbitrary and capricious. The USDA, the court said, relied on "factual findings directly contrary" to its 2001 findings, without providing a "reasoned explanation" for that choice. ${ }^{213}$ In so holding, the Ninth Circuit emphasized the broader political context: "There was a change in presidential administrations just days after the Roadless Rule was promulgated in 2001. Elections have policy consequences. But, State Farm teaches that even when reversing a policy after an election, an agency may not simply discard prior factual findings without a reasoned explanation."214

The U.S. Supreme Court also has held that where a prior policy "has engendered serious reliance interests," the agency must offer a reasoned explanation for disregarding those interests. ${ }^{215}$ This rule seeks to balance the "unfairness" of the policy change with "the government's interest in applying its new view."216

Again, the contrast between two cases from the Supreme Court's hard look trilogy illustrates the point. In Encino Motorcars, the Court found the DOL's policy change arbitrary and capricious in part because "[d]ealerships and service advisors [had] negotiated and structured their compensation plans" according to the agency's prior position. ${ }^{217}$ However, in Fox,

${ }^{209} 795$ F.3d 956 (9th Cir. 2015).

${ }^{210} I d$. at 959 .

${ }^{211}$ Id. at 960 (quoting Special Areas; Roadless Area Conservation, 66 Fed. Reg. 3244, 3254 (Jan. 12, 2001) (to be codified at 36 C.F.R. pt. 294)).

${ }^{212} I d$. at 962 (quoting Special Areas; Roadless Area Conservation; Applicability to the Tongass National Forest, 68 Fed. Reg. 75,136, 75,137 (Dec. 30, 2003) (to be codified at 36 C.F.R. pt., 294)).

${ }^{213}$ Id. at 968; $c f$. Nat'l Ass'n of Home Builders v. EPA, 682 F.3d 1032, 1038 (D.C. Cir. 2012).

${ }^{214}$ Vill. of Kake, 795 F.3d at 968.

${ }^{215}$ FCC v. Fox Television Stations, Inc., 556 U.S. 502, 515 (2009).

${ }^{216}$ Ronald M. Levin, "Hard Look Review, Policy Change, and Fox Television," 65 U. Miami L. Rev. 555, 567 (2011).

${ }^{217}$ Encino Motorcars, LLC v. Navarro, 136 S. Ct. 2117, 2126 (2016). 
the Court sanctioned wide ground for the FCC to change positions, no doubt in part because the "transition costs resulting from reliance on the former fleeting-expletives policy were not significantly involved . ..."218

Likewise, in Batalla Vidal v. Nielsen, the court pointed to reliance interests as key to its conclusion that the plaintiffs were entitled to an injunction of the Trump administration's attempted termination of the Deferred Action for Childhood Arrivals (DACA) program. ${ }^{219}$ That program allows "certain individuals without lawful immigration status who entered the United States as children to .... work, study, and keep building lives in this country." 220 Noting the extensive reliance interests of DACA recipients' families, employers, and educational institutions in shaping their lives, careers, and futures, the U.S. District Court for the Eastern District of New York found this alone "sufficient to render [the Department of Homeland Security's] supposedly discretionary decision to end the DACA program arbitrary and capricious." 221

\section{[3] Hard Look Review and the Trump Energy Policy}

Implementation of the Trump administration's energy policy has already put a tangle of legal issues before the courts.222 These judicial dustups are likely to become only more prevalent and complex with time. They are complex in part simply because of the vastness of the Trump administration's efforts. Yet they are also complex because of how hard look review tends to be implemented in practice. In this vein, how the administration's energy policy will fare before the judiciary on hard look challenges reduces to two key questions.

The first is whether the openly political nature of the administration's policies will help or hurt it. As precedent shows, politics can cut both ways. As the State Farm dissent recognized, policy shifts that trace directly to presidential elections gain some legal cover from the idea that an election reflects the democratic will of the people-or, at least, that electoral ritual can partially legitimize agencies' policy shifts. On the other hand, even as courts generally are reluctant to expressly address politics as a formal part of their arbitrary and capricious analysis, the reality may be that courts come at cases with a different orientation when it is clear politics undergirds their decision more than anything else. This may be in part because

${ }^{218}$ Levin, supra note 216, at 567.

${ }^{219} 279$ F. Supp. 3d 401 (E.D.N.Y. 2018).

${ }^{220} \mathrm{Id}$. at $406-07$.

${ }^{221} \mathrm{Id}$. at 431.

${ }^{222}$ See Lisa Heinzerling, “Unreasonable Delays: The Legal Problems (So Far) of Trump's Deregulatory Binge”, 12 Harv. L. \& Pol'y Rev. 13 (2018); Noll \& Grab, supra note 151. 
agencies' political motivations may incline them to play faster and looser with the facts. It also may be part of the explanation for studies that have shown higher affirmance rates by Democratic judicial appointees of "liberal" agency decisions, and vice versa. ${ }^{223}$ The smell of politics (or politics they dislike) puts judges' antennae up.

What is less clear is whether it is politics itself that gives courts umbrage, or if it is agency disingenuousness that invokes judicial skepticism when politics is involved-because the agency says it is acting for one reason but it obviously is acting for another. The medicine here is clear. Agencies and courts both should own up to what role politics plays in their decision making, so that the merits can be dealt with out in the open rather than through a distorted lens, or in code. Past administrations typically have not deemed it wise to be so brazen. ${ }^{224}$ However, the Trump administration appears already to be expressly invoking politics to justify its administrative decisions to some degree..$^{225}$

Of course, merely acknowledging the role of politics in their decisionmaking processes will not inoculate agencies from legal barrage, even if it may give them credit with the court for fair dealing. They still have to justify their choices. That, then, leads to the second question.

That question is whether any hard look review tripwires will hobble the Trump administration's energy efforts. At the outset of addressing this question, it is critical to emphasize that if hard look review is anything, it is highly granular, fact-specific, and context-dependent. ${ }^{226}$ So, just because one Trump regulatory U-turn survives judicial scrutiny does not mean another, even related, effort will as well.

What we can say is that, tactically at least, the Trump administration's repeal-everything-as-fast-as-possible approach has something to commend it. It renders arguments that the Obama-era rules need to stay in place because parties have detrimentally relied on them difficult indeed. These rules were not around long in the first place, and now, their shelf life already has been called into question.

${ }^{223}$ See Thomas J. Miles \& Cass R. Sunstein, “The Real World of Arbitrariness Review," 75 U. Chi. L. Rev. 761, 767 (2008).

${ }^{224}$ See Noll \& Grab, supra note 151, at 294.

${ }^{225}$ See Heinzerling, supra note 222, at 41, 46.

${ }^{226}$ See Mark Seidenfeld, "The Role of Politics in A Deliberative Model of the Administrative State," 81 Geo. Wash. L. Rev. 1397, 1456 (2013); see also Natural Res. Def. Council, Inc. v. SEC, 606 F.2d 1031, 1050 (D.C. Cir. 1979) (noting that the "stringency of our review" depends, among other things, on the "impartiality of the agency as regards the issue presented"). 
Where the Trump administration will have more trouble, then, is in procedurally and substantively justifying what it is doing on energy. Courts can be persnickety on agency procedure, especially when they sense something else is awry, ${ }^{227}$ and the Trump administration has already run into trouble on these grounds. Twice, in fact, the U.S. District Court for the Northern District of California rejected the BLM's efforts to delay the Waste Prevention Rule because the agency did not adequately explain itself. ${ }^{228}$ As one commentator has suggested, the administration's explanations for why it needs to delay Obama-era rules have seemed rushed and slapdash across the board, not just on energy - and often with reasoning that is "entirely circular: the agency needs to delay the effective date because the agency needs to delay the effective date. Stating a conclusion is not the same as explaining it." 229

Substantiating new or different energy rules may pose an even higher hurdle for the administration, at least in some cases. This is the hard look game. State Farm and its progeny expressly contemplate that agencies will change their policies, including for political reasons. Agencies, however, must then substantively justify their new policies as both legal and good. This is the hard work of the administrative state. It involves evidence and technical expertise and minutiae, all while acknowledging and addressing the impacts that proposed rules will have on society. Undoing prior rules, in other words, is entirely feasible. But the more well-built the prior rule is, the more difficult it is to undo-and the more quickly that work of rescission is done, the more likely it will not be up to par.

Certainly, the Trump administration inevitably will ground some of its choices in fact sufficiently to emerge from the gauntlet of judicial review. The Obama administration had good reasons for withdrawing federal lands from coal leasing, for instance, but those reasons do not foreclose others that might lead to an opposite conclusion. On some such decisions, Congress intentionally has given agencies wide berth, expecting that they will exercise their expertise or balance the public interest in a way that matches society's evolving needs over time. In such circumstances, courts are less likely to intervene.

In other cases, though, the factual record built by the Obama administration will be more difficult to discard. ${ }^{230}$ NHTSA has some leeway in

${ }^{227}$ See, e.g., Michigan v. EPA, 135 S. Ct. 2699 (2015); see also Louis J. Virelli III, "Deconstructing Arbitrary and Capricious Review," 92 N.C. L. Rev. 721, 743 (2014).

${ }^{228}$ See $\$ 21.03[1][\mathrm{a}]$, supra.

${ }^{229}$ Heinzerling, supra note 222 , at 43.

${ }^{230}$ See Nina A. Mendelson, "Agency Burrowing: Entrenching Policies and Personnel Before a New President Arrives," 78 N.Y.U. L. Rev. 557, 594-95 (2003). 
deciding how aggressive vehicle efficiency standards should be, but the EPA's finding that GHG emissions from mobile sources endanger public health and welfare rests on much more than a thin reed. Reversing that conclusion-or finding that electricity-sector GHG emissions need not be regulated, even if the President believes climate change is a "hoax"-will not be an easy task. The science simply points the wrong way. Likewise for onshore oil and gas: It may be that the Trump BLM can explain why the Obama BLM had it wrong on fugitive methane emissions, especially if it makes a new case for how the balance of public benefits and regulatory compliance costs comes out differently. But suggesting that natural gas on federal lands simply should be burned off at the same time the administration is clamoring for more domestic fossil fuel production-that logic would seem harder to sell.

Much of courts' hard work in the energy realm in the coming years, then, will be carefully examining each of these claims, deciding where the Trump agencies' records stack up and where they do not. The courts will engage in this endeavor against the broader backdrop of the hard look standard - a standard that is designed to often defer to agencies. No doubt, the Trump administration knew this as it developed, planned, and then implemented its energy policy. Prior studies have shown that agencies enjoy quite successful records in the courts against arbitrary and capricious challenges. Agencies' chances at prevailing may be as high as $90 \%$ in the Supreme Court ${ }^{231}$ and $70-75 \%$ in the various circuits of the U.S. Courts of Appeals. ${ }^{232}$ Moreover, as one commentator has shown, even when a court invalidates an agency's decision as arbitrary and capricious, that is not the end of the matter. Rather, agencies have a strong record of resuscitating their policies in these circumstances, successfully re-implementing their policies "in approximately $80 \%$ of the instances in which courts have originally remanded rules as arbitrary and capricious."233 Although, on average, it takes an agency two years to do this, in more than half of the cases analyzed, it took "less than a year." ${ }^{234}$

${ }^{231}$ See Adrian Vermeule, Law's Abnegation 191 (2016).

${ }^{232}$ See Frank B. Cross, "Decisionmaking in the U.S. Circuit Courts of Appeals," 91 Calif. L. Rev. 1457, 1503 (2003); Miles \& Sunstein, supra note 223, at 767; David Zaring, "Reasonable Agencies," 96 Va. L. Rev. 135, 173 (2010); see also Jacob Gersen \& Adrian Vermeule, “Thin Rationality Review," 114 Mich. L. Rev. 1355, 1358 (2016).

${ }^{233}$ William S. Jordan, III, “Ossification Revisited: Does Arbitrary and Capricious Review Significantly Interfere with Agency Ability to Achieve Regulatory Goals Through Informal Rulemaking?" 94 Nw. U. L. Rev. 393, 440 (2000). 
In short, the battle over what the nation's energy policy will be going forward will not stop with hard look review in the courts. It may well simply pause-or begin again-there.

\section{$\$ 21.05$ Conclusion}

The Trump administration wants an energy future that turns heavily back to the past. It seeks to return U.S. energy policy to a metamorphosed version of what existed prior to the Obama administration-a policy focused on domestic energy sources, domestic energy production, and achieving a new world order where the United States not only uses fossil fuels ubiquitously at home but dominates global exports of them. This is a policy, the administration says, not of domestic energy independence but of U.S. energy "dominance."

Whether the Trump administration will achieve such ambitious aspirations is highly questionable. Its policy play swims against quite strong realworld currents that have emerged in the energy sphere in the last decade, including the burgeoning emergence of renewables, increased emphasis on efficiency, and global pressure to address climate change. More directly, the implementation of this policy already has faced substantial legal pushback-and will only face more. To date, the Trump administration has notched both victories and significant defeats on this front. Many of these future challenges will turn on legal questions other than hard look review, but there is no question that doctrine will play a heavy role going forward. In this regard, if past is prologue, the future of the Trump energy policy is murky at best. Courts have been reluctant to rely solely on the political nature of policy flip-flops to overturn them as unlawful, but the more political such choices are, the more searching scrutiny they may receive.

And the Trump energy policy is-more than anything else-political at its core. 
Electronic copy available at: https://ssrn.com/abstract=345 